\title{
COLLECTIVE MUSIC MAKING AS A DEVELOPER OF A TEENAGE PERSONALITY AS A WHOLE
}

\author{
Irēna Andersone \\ University of Latvia, Latvia \\ Guntars Bernāts \\ University of Latvia, Latvia
}

\begin{abstract}
The modern era of advanced technology places people at the computer, but practical action is what allows young people to learn, express and realize themselves. Collaborative skills are one of the most important lifestyle skills for preparing adolescents for life. The main idea of human interaction is to help the adolescent to develop, which is one of the main components of life activity. It is designed to develop initiative, self-control and self-assessment. Successful development of the social skills of pupils takes place in the interaction between pupils and the adults and pupils, themselves in the socialisation process: mutual perception, assessment and influence.

Children and teachers may face a number of challenges when they come to school: children have different degrees of readiness for school, lack of readiness for the new psychological role, varying motivation to go to school, different levels of skills and abilities, so it is important to bring these children together more and create a more enjoyable time for them at school. One of the forms of learning that unites children definitely is collective music making, because learners act as a single team for a single purpose, allowing them to get to know each other better and become more open.

The topicality of this research is indicated by the issue of promotion of self-realization of adolescents and development of creativity, which is actualized in pedagogy, because only such a personality in the future would be able to compete successfully in the labour market by generating and offering their ideas.

Methods: As part of the study, the authors conducted a survey of small music collectives' ensemble leaders, which helped to reveal the formation of the collective musical experience of the learners in creative activities, developing both socialization and cooperation skills, as well as promoting the possibilities of self-realization of the adolescents.
\end{abstract}

Keywords: collective music making, instrument playing, cooperation skills, self-realization. 


\section{Introduction}

In a democratic society a human being is considered a unique value, living and learning among other human beings. The modern age of developed technologies forces the human being to sit in front of a computer, but it is the practical activities that allow the young people to learn something useful in their lives purposefully, deliberately and on their own accord, so they could express and realise themselves.

Collaboration skills are among the most essential life skills, necessary to prepare the pupils for their life activities. The main idea of Humanistic interaction is to get the student interested, provided him or her with an opportunity to discover and develop their own abilities, to continue to work independently, thus helping the student to develop, development being one of the main components of life activity. It is aimed at the development of initiative, self-control and self-evaluation. Successful formation of the students' social skills is achieved in the co-operation between the students and adults, as well as between the students themselves - in a socialisation process: mutually perceiving, evaluating and influencing (Gudjons, 1998; Matusov, 2009). A person cannot learn social skills without interaction with other people.

Studying the holistic development of the adolescent personality, one must understand the holistic approach in music pedagogy. Maruta Sīe connects the ancient Greek philosophy term "wholeness" to music in the following way: the human being develops and retains the unity of soul, mind and emotions in balance, for a harmonious personality, using the characterising elements of musical rhythm, melody, mode, harmony and other entities characterising the wholeness of music. This unites an individual with the wholeness of society, and then further with the united rhythm, harmony, order, spirituality and wholeness of the cosmos (Sīle, 2000).

Historical research of wholeness theory in the science of pedagogy revealed ideas that were accepted as the basis of the developed holistic approach from the perspective of the pedagogy of science:

- the holistic approach in the personality study assumes that elements of complex phenomena are connected and indivisible, and that changes in one element initiate changes in the rest of the whole. This requires the study of the whole instead of separate variables.

- complex pedagogic phenomena must be grasped as a whole;

- wholeness is something more than just the sum of its elements (Sïle, 2000).

Creation, performance and listening to music is made possible by musical experience. Although music is only perceived through sound and 
listening, this experience is universal, as the whole of the human being is involved in it - the body, emotions, mind and soul are involved in its creation. Creation of musical experience through repeated listening to the music alone is insufficient, as full-fledged musical experience is connected with practical activity creating and performing music. Humans since the most ancient times have been using different instruments for the creation, preservation and handing down of musical experience, like - human voice, percussion, string, wind and - the much later created - keyboard instruments. Human life and the existence of musical culture today cannot even be imagined. For the instruments in a musical group to sound nice and full, it takes the long-term and patient joint work of both the student and the teacher. A musical group is a unique collective in which various individuals are connected in different contexts (Lim, 2014).

Entering a school, children and teachers may encounter several problems:

- the children can display different levels of readiness for school,

- lack of preparedness for the new psychological role,

- differing motivation to attend school,

- different levels of skills, abilities and also talent.

One of the forms of learning that definitely unites the children, is collective music-making, as the students operate as a united team, for one purpose, allowing them to get better acquainted and become more open. The ability to establish and maintain relationships with people not only enriches one's life, it is also a basic part of self-respect (Smita \& Strika, 1998). While participating in a musical group, everyone also shows himself/herself as an individual (Murnighan, 1991).

\section{The topicality of the research}

The topicality of the present study is indicated by a question current in pedagogy and concerning the promotion of self-realisation and development of creativity of the adolescents, as only such a personality will be capable of competing successfully in the labour market, generating and offering unique ideas.

In order for an adolescent to develop as a competitive personality in the future labour market, it is important to establish the necessary personality traits that are stimulated by the process of creative education:

- a unique personality;

- a generally developed personality;

- a personality that can represent one's own new ideas;

- a competitive personality;

- a successful personality. 
The age of adolescence has always been a difficult one. Because of the technological revolution and digital opportunities, the adolescents spend more and more time in the virtual world, adapting to other adolescents, replicating the actions of the idols of their age, adopting their behaviour, values and way of thinking, thus abandoning the originality of their own personality (Geidžs \& Berliners, 1999). With all this taken into account, it is of great importance for the education of the adolescents to be the one ensuring that the adolescents preserve their uniqueness.

At the same time both practice and research shows that promotion of adolescents' motivation, their encouragement on the path to developing their musical interests is a real challenge for the leader of a musical group, as collective music-making requires perseverance, strict discipline, but is also forming the sense of social responsibility within the group. Collective music-making has a beneficial effect on the improvement of general social skills and co-existence, it raises the motivation for learning and attending extra-curricular activities, as it improves attention, organisation and selfanalysis (Bonshor, 2018).

Playing musical instruments is the activity that offers the best opportunity for the development of artistic skills, emotionality and understanding of musical values a student has, simultaneously encouraging the development of musical intellect. The research by education researchers has proven that learning to sing, reading scores and playing an instrument can be a teaching method by which not only the students are introduced to the world of art, but it also develops those skills and potencies of the students that are useful for all other subjects, like mathematics or languages, thus providing an opportunity for the student's self-realisation (Fišers, 2005).

The teachers at Latvian professional music schools employ various exercise systems and methodological techniques in order to help the students to improve the technical elements of instrument playing and to acquaint them with the rich musical culture. In creatively organised study, students acquire knowledge about the expression of the musical language, stylistic, genre-specific and other characteristics of a musical piece.

Collective music-making is an important part of music education, influencing the comprehensive development of an adolescent's personality it develops intellectual abilities and those of perception, emotional responsiveness to music, artistic fantasy and creativity that are substantial parts of any innovative activity of the $21^{\text {st }}$ century (Kumik, 2017). This leads to the conclusion that both the individual and collective musicmaking skills are developed.

This statement is supported by the achievements of the most talented students of the Latvian music schools at local and international music competitions and festivals. There are many examples, it is important to 
highlight just a few: Ëriks Katkevičs, a learner of the $8^{\text {th }}$ violin class at the Jurmala Music School, won the $1^{\text {st }}$ prize in the International Cote d'Azur Piano Competition of the Conservatory of Nice (France) (21-27 October 2018). Eduards Levša won Grand Prix at $36^{\text {th }}$ Pärnu Accordion Music Festival in Pärnu (Estonia) on October 26, 2018, Sandija Leja won $1^{\text {st }}$ prize at XIX Concours International de Piano in Paris, France, April 22-23, 2019 (Jūrmalas mūzikas vidusskola (Jurmala Secondary Music School), 2019).

But Latvia stands out among other countries - and can pride itself on the fact - that whatever rapid social economic changes have affected the country during the recent decades, it has been able to retain professionallyoriented musical education. There are 143 music and art schools in Latvia founded by municipalities and partly supported by the state. Foreign visitors and experts have repeatedly pointed out the phenomenon of music and art education in Latvia, not only the large number of children's music and art schools, but also musical education in schools (Matisāne, 2011). Its importance for the development of professional musicians and music teachers is undeniable, but its greatest contribution is the preservation and development of the values of Latvian cultural life, by raising educated music lovers - people that love music and are interested in it, attend concerts and consider music-making in amateur groups an integral part of their lives.

Therefore the main task for a teacher of collective music-making is to raise the students' motivation for participating in the field of music. Achieving this goal is getting increasingly harder in our times, as the changes in society also change the modern child's value orientation, the range of his/her needs and interests grows wider and more varied, changing the sphere of motivation along with it.

Government support for the professionally-oriented music education has currently decreased. Changes in society and students make demands on the teacher for not only a high level of professional competence and knowledge, but also one's own view of the world, individual stance and constant learning.

Collective music-making (playing an instrument or singing) is the activity offering the best opportunity for development of adolescents' skills. The adolescents joining groups form their personalities (Argyris, 1985; Garleja, 2003).

Studying collective music-making, as the means of developing an adolescent's personality as a whole, lead to the conclusion that this development will only take place if a number of factors interact together. Such development of adolescents' personalities as a whole is conditioned by the interest of the adolescents, their collaboration skills, socialisation, emotionality, self-analysis, self-realisation, cognitive abilities, their 
understanding of music, artistic abilities and their skills of collective musicmaking, i.e. the skills of either singing or playing an instrument (see Figure).

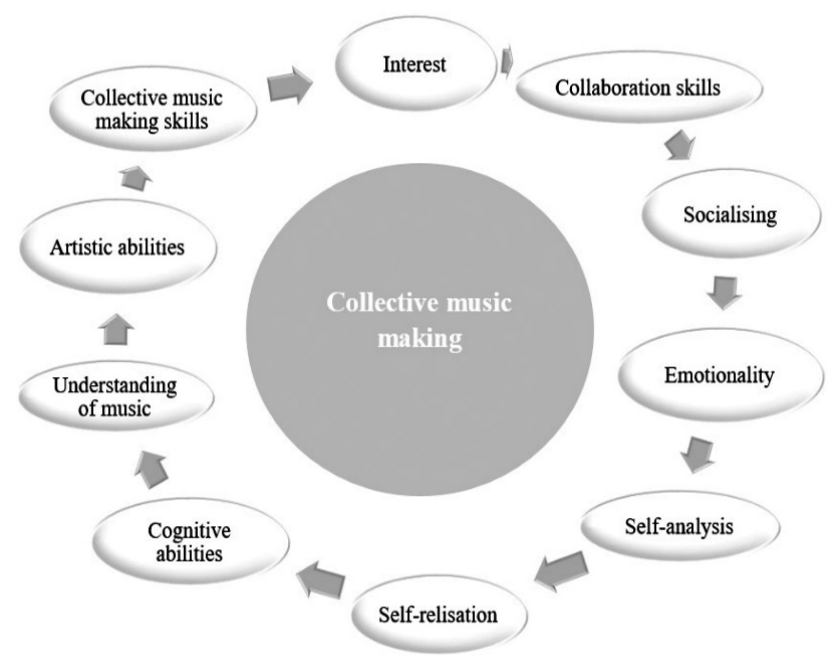

Figure. Collective music making as an activity developing the adolescents' personality as a whole (authors' developed concept)

\section{Collective music making - in the context of the reform of the Latvian education system}

As the result of the reduction in funding (government grants for institutions of cultural education) in 2009 a reform of cultural education was initiated, applying adjustments to the content of professionally oriented education programmes (Latvijas Republikas Kultūras ministrija (Ministry of Culture of Latvia Republic), 2011) and in 2010 a 2 flow education programme model for musical schools was introduced, with a basic programme and an extended programme (Kultūrizglìtības attīstība (Development of cultural education) 2009-2012, 2010) in which emphasis is placed on collective music-making and the proportion of theoretical and individual lessons is reduced. Along with that the children, adolescents and youth are encouraged to participate in different music groups- choirs, vocal groups, orchestras, creatively forming the music-making process of the group, thus resulting in the following benefits for the students:

- substantially promoted development of musical, intellectual and emotional abilities;

- significantly promoted acquisition of experience in collective and individual musical activity;

- developed creative abilities in music; 
- developed ability to orientate oneself in musical genres and styles (Latvijas Nacionālais kultūras centrs (Latvian National Center for Culture), 2011).

\section{The results of the survey of the leaders of Latvian collective music-making - the teachers}

Studying the theoretical ideas in the field of music teaching and performing their analysis, within the framework of the present study the authors created a questionnaire, so as to get insight from the group leaders, regarding the development of their pupils' collective music-making experience, development of socialisation and collaboration skills, and the promotion of opportunities for self-realisation.

40 leaders of different music groups (choirs, orchestras, chamber ensembles and vocal groups) participated in this survey, of those 4 were leaders of orchestras, 9 were leaders of vocal groups, 11 were leaders of choirs and 16 - leaders of instrumental ensembles. Respondents were selected to represent almost all types of collective music groups in Latvia. The average experience of pedagogy work - 14 years (in the range of 1-40 years). Most of the participants (22 of those surveyed) lead collective music-making activities in professionally-oriented music schools - 11 in specialist education and 7 in general education schools.

The questions in the survey were mostly formulated in such a way that the respondents had the opportunity to respond in the affirmative or the negative, justifying their response.

The question: "Do you support the current emphasis in Latvian professionally-oriented education on collective music-making and the increase in the number of lessons? Please, respond with either "Yes" or "No" and provide the reasoning behind your response!" was answered with "Yes" by 37 respondents, while three responded in the negative, objecting to the same payment for both the individual and group lesson, also stressing the need for a reasonable balance between individual and collective musicmaking lessons in the curriculum.

The question "Is collective music-making the right form of activity for developing an adolescent's personality as a whole? Please, respond with either "Yes" or "No" and provide the reasoning behind your response!" received 35 affirmative responses, while two responded with "No", and three more provided no answer to the question. The respondents justified their responses by saying that socialisation and collaboration with other adolescents is fundamental to adolescents, therefore improved communication skills, a growth in discipline, and the promotion of general and musical skills are developed through collective music-making activities. 
To the question "Which are the skills learned during collective musicmaking that promote the development of an adolescent's personality? (Please, name at least 3)" most of the participants responded by emphasising the following: listening skills (14), collaboration skills (12) and the development of responsibility (12).

The question "Do you believe that collective music-making activities promote the creative self-expression of adolescents? Please, respond with either "Yes" or "No" and provide the reasoning behind your response!" most of the teachers responded with "yes", while there were two responses of "No", one - "do not know" and one - "not in particular". This shows that the group leaders do believe that collective music-making activities contribute to the creative self-expression of adolescents.

The question "Which factors in the collective music-making process most help the development of adolescents' socialisation skills?" received interesting, but extremely varied responses. Many respondents emphasised the importance of collaboration for the achievement of common goals (11 respondents), but the positive atmosphere in the rehearsal process was also nominated as important (9 respondents).

And finally the question important in the context of the present study: "Are the socialisation skills necessary for playing in a group promoting the development of personality? Please, respond with either "Yes" or "No" and provide the reasoning behind your response!" nearly all respondents gave an affirmative answer, while only one was of the opinion that it cannot be judged that simply.

Therefore this leads to the conclusion that collective music-making promotes the development of socialisation skills, which are important in the development of personality. The conclusions from the empirical study regarding the formation of responsibility are also important, as are those about the development of listening and collaboration skills in the process of collective music-making. The development of personality in the process of collective music-making was indicated by the responses with statements such as: “...the adolescents' self-confidence grows, their communication improves, during the concerts they develop an increasing ability to control their emotions in the critical moments". "... the adolescents become more responsible, diligent, independent, and by collaborating they learn to accept differing opinions".

\section{Conclusions}

The survey resulted in the conclusion that it is particularly important to promote the formation of the students' collective musical experience through creative activity, by developing both instrument skills, and 
socialisation and collaboration skills. A respondent who provided a very comprehensive answer did so in the context of the present study: "...these are skills that should be transferred to everyday life in the relationship with society - to listen, avoid conflicts, to provide support."

Collective music-making can be considered as a means of developing an adolescent's personality as a whole, if the adolescent has:

- developed elements of singing and instrument playing skills;

- a formed idea of the richness of musical culture;

- knowledge of the means of expression of the musical language, stylistic, genre-specific and other characteristics of a musical piece;

- developed general abilities - perception and intellectual abilities, emotional responsiveness to music, creativity;

- developed individual and collective music-making skills;

- strengthened their sense of national and patriotic belonging.

The carried out practical research proves the validity of the findings of well-known music scientists (Bonshor M., Lim M.C., Kumik E.) as well as the belief of the authors regarding the importance of the experience gained in the process of collective music making in the personality development of a teenager.

\section{References}

Argyris, C. (1985). Strategy, Chenge, and Defisive Routines. Boston: Pitman.

Bonshor, M. (2018). The Confident Choir: A Handbook for Leaders of Group Singing. Lanham: Rowman\&Littlefield. [e-book]. Retrieved from https://www.amazon.co.uk/ Confident-Choir-Michael-Bonshor/dp/153810279X.

Garleja, R. (2003). Darbs, organizācija un psiholoǵija (Work, organization and psychology). Rīga: Raka.

Geidžs, N. L., \& Berliners, D. C. (1999). Pedagogiskā psihologija (Educational psychology). Rìga: Zvaigzne ABC.

Gudjons, H. (1998) Pedagoǵijas pamatatzinas (Basic principles in pedagogy). Rīga: Zvaigzne ABC.

Fišers, R. (2005). Mācīsim bērniem mācīties (Let's teach children to learn). Rīga: RaKa.

Jūrmalas mūzikas vidusskola (Jurmala Secondary Music School) (2019). Apsveicam audzēknnus ar panākumiem konkursos (Congratulations to the learners on their success in competitions). Retrieved from https://muzikasskola.jurmala.lv/2018/12/14/ apsveicam-audzeknus-ar-panakumiem-konkursos-2/.

Kultūrizglītības attīstība 2009-2012 (Development of cultural education 2009-2012) (2010). Retrieved from http://tms.lv/wp-content/uploads/2010/09/KI_reforma.pdf.

Kumik, E. (2017). Ensemble Music-Making as an Important Element of a Young Musician's Training. Daugulis, E. (Eds.) Music Science Today: the Permanent and the Changeable 1 (9), Scientific Paper. Daugavpils: Daugavpils University Academic Press Saule, p. 110-115. 
Latvijas Nacionālais kultūras centrs. (Latvian National Center for Culture) (2011). Daudzveidiggas mācību metodes un mācỉbu priekšmetu programmu izveides metodika mūzikas profesionālās ievirzes izglīīibā. 1.1. Koncepcija un tās realizācija metodiskajā materiālā. Retrieved from https://www.lnkc.gov.lv/nozares/kulturizglitiba/metodiskiemateriali-muzikas-izglitiba/.

Latvijas Republikas Kultūras ministrija (Ministry of Culture of Latvia Republic). Gada publiskais pārskats (Annual Public Report) 2010 (2011). Retrieved from https://www. $\mathrm{km}$. gov.lv/uploads/ckeditor/files/parskati files/KM_PARSKATS2010_01_07_2011.pdf.

Lim M. C. (2014). Inpursuit of harmony: The social and organisational factors in a professional vocal ensemble. Psychology of Music, Vol. 42 (3), 307-324.

Matisāne, I. (2011). Reforma tricina mūzikas un mākslas izglitïbas pamatus (The reform shakes the foundations of music and art education). Retrieved from https://lvportals. lv/viedokli/228320-reforma-tricina-muzikas-un-makslas-izglitibas-pamatus-2011.

Matusov, E. (2009). Journey Into Dialogic Pedagogy. New York: Nova Science Publishers Inc.

Murnighan, J. K., \& Conlon, D. E. (1991). The dynamics of intense workgroups: A study of British stringquartets. Administrative Science Quarterly, 36 (2), 165-186.

Sīle, M. (2000). Veseluma pieeja bērna attīstïbā klavierspēles mācību procesā (A holistic approach to child development in the piano learning process). Rīga, LU. Promocijas darbs.

Smita, K., \& Strika, L. (1998). Mācišanās traucējumi (Learning disabilities). Rīga: RaKa. 